\title{
Quality characteristics and antioxidant activity of 'Hwajeon' prepared using tomato powder
}

\author{
Yoon-Jung Jung ${ }^{1}$, Eun-Sun Hwang ${ }^{1,2 *}$ \\ ${ }^{1}$ Department of Human Ecology, Major in Nutrition and Culinary Science, Hankyong National University, \\ Anseong 17579, Korea \\ ${ }^{2}$ School of Wellness Industry Convergence, Major in Food and Nutrition, Hankyong National University, \\ Anseong 17579, Korea
}

\section{토마토 분말 첨가 화전의 품질 특성 및 항산화 활성}

\author{
정윤정 ${ }^{1} \cdot$ 황은선 ${ }^{1,2 *}$ \\ ${ }^{1}$ 한경대학교 생활과학과 영양조리과학전공, ${ }^{2}$ 한경대학교 웰니스산업융합학부 식품영양학전공
}

\begin{abstract}
The present study was conducted to investigate the quality characteristics and antioxidant activities of 'Hwajeon' that was prepared by replacing glutinous rice flour with $0,4,8$, and $12 \%$ of tomato powder. The moisture content in 'Hwajeon' was noted to be $\mathbf{4 2 . 6 0 - 4 6 . 5 9 \%}$, with the highest moisture content present in 'Hwajeon' without the added tomato powder. The addition of tomato powder revealed a decreasing tendency of the moisture content compared to that in the control group. There was no statistically significant difference in the crude protein levels of 'Hwajeon', based on the content of added tomato powder, however, the contents of ash and crude fat increased with increasing amounts of tomato powder. The sugar content in 'Hwajeon' increased in accordance with the addition of tomato powder, whereas the $\mathrm{pH}$ tended to decrease. Regarding the determination of chromaticity, the value of $L^{*}$ decreased and those of $\mathrm{a}^{*}$ increased with increasing levels of tomato powder. The total polyphenol and total flavonoid contents increased with increasing levels of tomato powder. The antioxidant properties investigated by evaluating the DPPH and ABTS radical scavenging activities and reducing powder, were significantly higher than those of the control, and proportionally increased with increasing contents of tomato powder. These results suggest that the addition of $4-12 \%$ of tomato powder could be applied in the preparation of 'Hwajeon'.
\end{abstract}

Key words : tomato, Hwajeon, quality characteristics, polyphenol, antioxidant activity

서 론

화전(花前)은 삼월 삼짇날 만들어 먹었던 절식 중의 하나 로 찹쌀가루를 끓는 물로 익반죽하여 동글납작한 모양으로 빚은 후 기름에 지져 익히고, 계절에 따라 진달래, 장미, 국화 등의 꽃잎을 붙여 꾸미는 떡이다(Lee 등 2003; Jang과 Park, 2003). 화전은 꽃부꾸미, 꽃지지미, 꽃달임 등으로도 불리며,
꿀, 시럽, 조청, 설탕 등을 묻혀 달콤하게 먹는 후식류의 일종 이다(Jang과 Park, 2003). 최근 우리 전통음식에 대한 관심이 높아지면서 집청액 종류에 따른 화전의 특성(Jang과 Park, 2003), 기름의 양과 지지는 시간에 따른 화전의 특성(Lee 등, 2003) 등에 관한 선행 연구가 수행되었고, 화전 제조 시 전통 적인 조리법을 기본으로 하여 생리활성 성분이 풍부하다고 알려진 머루즙, 찰흑미, 강황 등의 부재료를 첨가하여 영양

${ }^{*}$ Corresponding author. E-mail : ehwang@hknu.ac.kr, Phone :+82-31-670-5182, Fax : +82-31-670-5189

Received 05 January 2021; Revised 19 January 2021; Accepted 20 January 2021.

Copyright (c) The Korean Society of Food Preservation.

This is an Open Access article distributed under the terms of the Creative Commons Attribution Non-Commercial License (http://creativecommons.org/licenses/by-nc/4.0) which permits unrestricted non-commercial use, distribution, and reproduction in any medium, provided the original work is properly cited. 
및 기능적인 효과와 관능적인 특성을 동시에 증진시키기 위 한 연구도 진행되었다(Han과 Surh, 2017; Lee 등, 2011; Surh와 Koh, 2014).

토마토(Lycopersicon esculentum Mill.)는 라틴아메리카가 원산지인 가지과의 한해살이 작물로 전 세계적으로 널리 재 배되고 있으며, 라이코펜, $\beta$-카로틴, $\alpha$-토코페롤, 폴리페놀 화 합물 등의 생리활성 물질들이 함유되어 있다(Giovannucci 등, 1995). 특히, 라이코펜은 대표적인 카로티노이드 물질로 토마토의 붉은색을 나타내는 천연색소 성분으로 잘 익은 토 마토일수록 더 풍부하며, 과육보다 껍질에 그 함량이 많은 것 으로 알려져 있다(Chandra 등, 2012). 토마토에 함유된 라이 코펜은 항산화 능력이 탁월하고, 전립선암, 유방암, 폐암 등 다양한 암의 예방, 항산화 효능, 심혈관계 질환의 예방, 면역 체계 조절, 노화 방지와 퇴행성 질환의 억제 등의 효능이 다양 한 in vitro 및 in vivo 실험을 통해 입증되었다(Cheng 등, 2019; Marti 등, 2016; Palozza 등, 2011; Rowles 등, 2018; Sahin 등, 2019).

우리나라에서는 토마토를 주로 익히지 않고 생과로 섭취 하는 반면에, 외국에서는 토마토를 올리브 오일과 함께 오븐 에 굽거나 고기 등의 재료와 함께 조리하거나 파스타, 소스, 페이스트, 케첩 등의 가공된 형태로 이용하는 경우가 많다. 선행연구를 통해 토마토에 함유된 라이코펜과 $\beta$-카로틴은 지 용성 성분으로 토마토를 열처리를 통해 기름과 함께 조리해 먹었을 때 체내 흡수율과 이용률이 높아짐이 확인되었다 (Chaudhary 등, 2018; Martinez-Huelamo 등, 2016). 따라서 토마토의 다양한 조리법을 개발하고 활용하여 기능성 성분의 흡수와 이용도를 높이기 위한 연구가 필요하다. 현재까지는 토마토를 베이글(Kim 등, 2016a), 국수(Kim 등, 2015), 소시 지(Na와 Joo, 2012), 머랭 쿠키(Kim 등, 2016b), 죽(Choi와 $\mathrm{Kim}, 2015)$, 크래커(Kim 등, 2017) 등에 첨가하여 제조조건 의 최적화 및 품질특성을 탐색한 연구가 진행되었으나, 토마 토를 화전 제조에 활용한 연구는 이루어지지 않았다.

따라서 본 연구에서는 다양한 생리활성물질이 풍부하고 항산화 활성이 우수한 토마토 분말을 다양한 비율로 첨가하
여 화전을 제조한 후, 이화학적 품질특성, 항산화 물질의 함 량 및 항산화 활성을 측정함으로써 화전 제조에 토마토의 적 용 가능성을 탐색하였다.

\section{재료 및 방법}

\section{실험재료 및 시약}

본 연구에 사용한 토마토 분말은 맑은 들(Hongcheon, Korea)에서 제조하고, 신선약초(Seoul, Korea)에서 소분한 것을 구입해 사용하였다. 찹쌀(Anseong, Korea), 식용유(CJ Cheiljedang, Incheon, Korea), 소금(Chungjungone, Yongin, Korea)은 시판품을 구입해 사용하였다. Gallic acid, catechin, Folin-Ciocalteu's phenol reagent, 1,1-dipheny1-2-picrylhydrazyl (DPPH)는 Sigma-Aldrich Chemical Co.(St. Louis, Mo, USA)에서 구입하였고, 2,2'-azino-bis(3-ethylbenzothiazoline-6sulfonic acid) diammonium salt(ABTS)는 Flunk(Hekdelberg, Germany)에서 구입하였다. 그 외 시약들은 Sigma-Aldrich Chemical Co.와 Jencei Chemical Co., Ltd.(Tokyo, Japan)에 서 구입하여 실험에 사용하였다.

\section{화전 제조}

화전은 선행연구(Han과 Surh, 2017; Lee 등, 2003; Lee 등, 2011; Surh와 Koh, 2014)를 참고하여 여러 차례 예비실험을 통해 Table 1과 같은 배합비로 제조하였다. 예비실험을 거쳐 화전을 제조하고 예비 관능평가를 실시한 결과, 토마토 분말 이 $12 \%$ 이상이 되면 화전 특유의 쫄깃한 조직감이 감소하고, 관능적인 특성이 낮아짐을 확인하여 토마토 분말은 최대 $12 \%$ 까지 첨가하는 것으로 결정하였다. 토마토 분말을 첨가 하지 않고 제조한 화전을 대조군으로 하였고, 실험군은 대조 군에 사용한 찹쌀가루 대신 $4,8,12 \%$ 를 토마토 분말로 대체 하여 제조하였다(Fig. 1). 찹쌀가루는 찹쌀을 수돗물에 5 번을 씻어 6 시간 수침한 후 건져 30 분 동안 체에 받쳐 물기를 제거 한 후 방앗간에서 1 회 분쇄하여 제조하였다. 찹쌀가루에 각 분량의 토마토 분말을 넣고 끓여서 식힌 물 $\left(50 \pm 2^{\circ} \mathrm{C}\right) 30 \mathrm{~mL}$

Table 1. Formula for 'Hwajeon' made with different amounts of tomato powder')

\begin{tabular}{ccccc}
\hline Ingredient & \multicolumn{3}{c}{ Tomato powder (\%) } \\
\cline { 2 - 5 } & 0 & 4 & 8 & 12 \\
\hline Glutinous rice flour $(\mathrm{g})$ & 100 & 96 & 92 & 88 \\
Tomato powder $(\mathrm{g})$ & 0 & 4 & 30 & 30 \\
Water $(\mathrm{mL})$ & 30 & 30 & 0.5 & 0.5 \\
\hline Salt $(\mathrm{g})$ & 0.5 & 0.5 & 30 \\
\hline
\end{tabular}

\footnotetext{
${ }^{1)}$ Tomato powder $(4,8$ and $12 \%)$ was added based on the total amount of glutinous rice flour.
} 


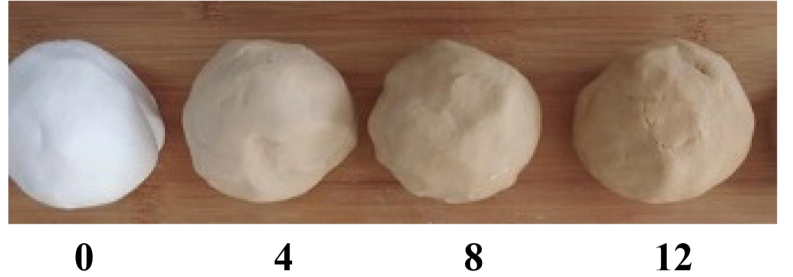

Tomato powder $(\%)$

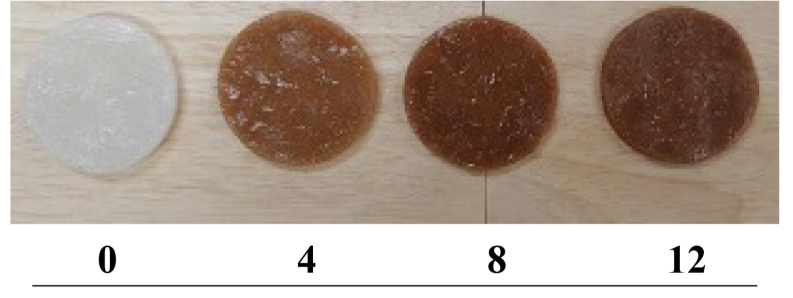

Tomato powder $(\%)$

Fig. 1. Dough and 'Hwajeon' added with different amounts of tomato powder.

를 넣어 익반죽한 후에 $20 \mathrm{~g}$ 씩 반죽을 떼어 지름 $4 \mathrm{~cm}$ 크기 의 동글납작한 모양으로 성형하였다. 프라이팬에 식용유를 5 $\mathrm{mL}$ 를 넣어 20 초 동안 달군 후 찹쌀 반죽을 넣어 지져 익혔 다. 완성된 토마토 화전은 실온에서 1 시간 동안 식힌 후, 분 석용 시료로 사용하였다.

\section{일반성분 함량 측정}

찹쌀가루, 토마토 분말 및 화전의 일반성분 함량은 $\mathrm{AOAC}$ (1995)의 방법에 따라 분석하였다. 수분은 $105^{\circ} \mathrm{C}$ 로 맞춘 드 라이오븐(EYELA, Tokyo, Japan)에서 건조하여 정량하였고, 조회분은 $600^{\circ} \mathrm{C}$ 회화로(Jeil, Seoul, Korea)에서 회화시켜 측정 하였다. 조단백질은 자동 단백질 분석기(Kjeltec 2400 AUT, Foss Tecator, Eden Prairie, MN, USA)를 이용하여 semimicro-Kjeldhl법으로 분석하였고, 조지방은 Soxhlet 추출기 (Soxtec System HT 1043, Foss Tecator)를 사용하여 diethyl ether로 추출하여 정량하였다.

\section{당도 및 $\mathrm{pH}$ 측정}

화전의 당도와 $\mathrm{pH}$ 측정을 위해 시료 표면에 묻은 식용유 를 키친타올을 이용하여 제거한 후에 잘게 잘라주었다. 잘게 자른 시료 $5 \mathrm{~g}$ 에 $95 \%$ 증류수 $10 \mathrm{~mL}$ 를 첨가하여 vortex mixer로 혼합한 후에 $40^{\circ} \mathrm{C}$ 에서 10 분 동안 초음파 추출을 한 후에, $16,700 \mathrm{rpm}$ 에서 30 분간 원심분리(Mega 17R, Hanil Co., Incheon, Korea)하여 상등액을 얻었다. 당도는 상등액을 취하여 당도계(PR-201 $\alpha$, Atago Co., Tokyo, Japan)로 측정하 였다. $\mathrm{pH}$ 는 상등액을 취하여 $\mathrm{pH}$ meter(420 Benchtop, Orion Research, Beverly, MA, USA)로 측정하였다.

\section{경도 측정}

화전 제조를 위해 만든 반죽과 팬에 부쳐 완성한 화전의 경도는 Texture analyzer(CT3 10K, Brookfield. Middleboro, MA, USA)를 사용해 texture profile analysis(TPA)로 측정하 였다. 제조한 시료를 plate의 중앙에 놓고 반복 압착실험 (two-bite test)을 3회 반복 측정하여 평균값을 구하였다. 측정
에 따른 probe는 TA11/1000, target type: \% deformation, target value: $50 \%$, trigger load: $10 \mathrm{~g}$, test speed: 0.50 $\mathrm{mm} / \mathrm{sec}$, load cell: $10 \mathrm{~kg}$ 으로 설정하였다.

\section{색도 측정}

화전 반죽과 팬에 부쳐 완성한 화전의 색도는 색차계 (Chrome Meter CR-300, Minolta, Tokyo, Japan)를 이용하여 명 도( $\mathrm{L}^{*}$, lightness), 적색도 $\left(\mathrm{a}^{*}\right.$, redness), 황색도( $\mathrm{b}^{*}$, yellowness)를 측정하였다. 표준색 보정은 $\mathrm{L}^{*}, \mathrm{a}^{*}, \mathrm{~b}^{*}$ 값이 각각 97.10 , $+0.24,+1.75$ 인 백색 표준판을 사용하였다.

\section{총폴리페놀 및 총플라보노이드 함량 분석}

화전은 $80 \%$ 에탄올에 추출하여 적절한 농도로 희석한 후 총폴리페놀 및 총플라보노이드 분석을 위한 시료로 사용하였 다. 적절한 농도로 희석한 시료 $0.5 \mathrm{~mL}$ 에 $2 \mathrm{~N}$ Folin 시약 $0.5 \mathrm{~mL}$ 를 혼합한 뒤 3 분간 실온에서 반응시킨 후, $2 \%$ sodium carbonate $1.5 \mathrm{~mL}$ 를 첨가한 뒤 2시간 동안 암소에서 반응시켰다. 반응물은 microplate reader(Infinite M200 Pro, Tecan Group Ltd., San Jose, CA, USA)를 이용하여 $760 \mathrm{~nm}$ 에서 흡광도를 측정하였다. 시료에 함유된 총폴리페놀 함량 은 gallic acid의 표준곡선 $(6.25-100 \mu \mathrm{g} / \mathrm{mL})$ 으로 시료 $100 \mathrm{~g}$ 당 함유된 gallic acid equivalent(GAE)로 표시하였다.

총플라보노이드 함량은 시료 추출액 $1 \mathrm{~mL}$ 와 $2 \%$ aluminium chloride methanolic solution $1 \mathrm{~mL}$ 를 혼합하여 실온에서 15 분 동안 반응시킨 후에 $430 \mathrm{~nm}$ 에서 흡광도를 측정하였다. 시 료에 함유된 총플라보노이드 함량은 quercetin의 표준곡선 $(6.25-100 \mu \mathrm{g} / \mathrm{mL})$ 을 이용하여 시료 $100 \mathrm{~g}$ 당 함유된 quercetin equivalent $(\mathrm{QE})$ 로 표시하였다.

\section{항산화 활성 측정}

화전의 항산화 활성은 DPPH 라디칼 소거활성(Cheung 등, 2003), ABTS 라디칼 소거활성( $\operatorname{Re}$ 등, 1999) 및 환원력(Oyaizu, 1986)으로 측정하였다. DPPH 라디칼 소거활성을 측정하기 위해 화전 추출액 $100 \mu \mathrm{L}$ 를 96-well plate에 넣고 $0.2 \mathrm{mM}$ 
$\mathrm{DPPH}$ 용액 $100 \mu \mathrm{L}$ 를 첨가한 후 $37^{\circ} \mathrm{C}$ 에서 30 분간 반응시켰 다. $515 \mathrm{~nm}$ 에서 microplate reader로 흡광도를 측정하고, 아 래 식에 의해 계산하였다.

\section{$\mathrm{DPPH}$ 라디칼 소거활성(\%)}

$=(1-$ 시료첨가구의 흡광도 / 시료 무첨가구의 흡광도 $)$ $\times 100$

$\mathrm{ABTS}$ 라디칼 소거활성은 $7.0 \mathrm{mM}$ ABTS와 $2.45 \mathrm{mM}$ potassium persulfate를 실험 24시간 전에 암소에서 반응시켜 ABTS 양이온을 형성시킨 후 $735 \mathrm{~nm}$ 에서 흡광도 값이 $0.17 \pm$ 0.03 이 되도록 에탄올로 희석하여 사용하였다. 화전 추출액 $100 \mu \mathrm{L}$ 를 96-well plate에 넣고 흡광도를 맞춘 ABTS 용액 $100 \mu \mathrm{L}$ 를 첨가한 후 $37^{\circ} \mathrm{C}$ 에서 30 분간 반응시켰다. Microplate reader를 사용하여 $732 \mathrm{~nm}$ 에서 흡광도를 측정하고, 아래 식 에 의해 계산하였다.

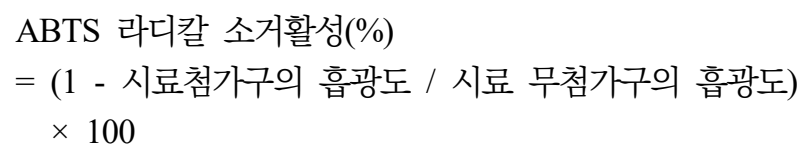

환원력은 화전 추출액 $1 \mathrm{~mL}$ 에 인산 완충액 $(200 \mathrm{mM}, \mathrm{pH}$ 6.6) 및 $1 \%$ 의 potassium ferricyanide $1 \mathrm{~mL}$ 를 차례로 가한 다음 $50^{\circ} \mathrm{C}$ 에서 20 분간 반응시킨 후에 $10 \% \mathrm{TCA}$ 용액을 1 $\mathrm{mL}$ 첨가하여 $13,500 \mathrm{~g}$ 에서 15 분간 원심분리하여 상등액을 얻었다. 상등액 $1 \mathrm{~mL}$ 에 증류수 및 ferric chloride를 각각 1 $\mathrm{mL}$ 씩 가하여 혼합한 후 $720 \mathrm{~nm}$ 에서 흡광도를 측정하여 환 원력으로 나타냈다.

\section{통계분석}

모든 결과는 3 회 반복실험에 대한 평균(mean) \pm 표준편차
(SD)로 나타내었다. 실험결과에 대한 통계처리는 R-Studio (Version 3.5.1, Boston, MA, USA)를 이용하여 평균과 표준 편차로 나타내었고, 각 처리군 간의 유의성에 대한 검증은 ANOVA를 이용하여 유의성을 확인한 후, $\mathrm{p}<0.05$ 수준에서 Duncan's multiple range test를 이용하여 분석하였다.

\section{결과 및 고찰}

\section{일반성분 조성}

실험에 사용된 찹쌀가루와 토마토 분말 및 제조한 화전의 일반성분을 분석한 결과는 Table 2 와 같다. 찹쌀가루의 수분 은 $36.83 \%$ 로 토마토 분말의 수분 함량인 $13.58 \%$ 에 비해 높 았고, 찹쌀가루의 회분은 $0.54 \%$ 로 토마토 분말의 회분 함량 인 $6.98 \%$ 에 비해 낮게 나타났다. 토마토 분말의 조단백질 및 조지방 함량은 각각 $1.65 \%$ 및 $2.77 \%$ 로 찹쌀가루에 비해 통 계적으로 유의성 있는 수준에서 높게 나타났다.

토마토 분말을 첨가하지 않고 제조한 화전의 수분은 $46.59 \%$ 로 가장 높았고, 토마토 분말 함량이 $4-12 \%$ 까지 증가 함에 따라 수분은 42.60-45.65\%로 대조군에 비해 감소하는 경향을 나타냈다. 이는 물에 침지해 분쇄한 찹쌀가루보다 건 조하여 제조한 토마토 분말의 수분함량이 낮기 때문으로 토 마토 분말 함량이 증가할수록 화전의 수분도 감소한 것으로 사료된다. 이와 같은 결과는 토마토 분말을 첨가한 설기떡 (Lee와 Chun, 2008), 토마토 분말 첨가 국수(Kim 등, 2015), 토마토 분말 첨가 죽(Choi와 Kim, 2015)의 연구에서도 토마 토 분말 첨가량이 증가할수록 제품의 수분함량도 낮게 나타 나 본 실험의 결과와 유사한 경향성을 보였다.

회분은 대조군에서는 $0.49 \%$ 로 가장 낮았고, 토마토 분말 첨가량에 비례하여 $0.68-1.08 \%$ 로 증가하였다. 이는 찹쌀가루 에 비해 토마토 분말의 회분 함량이 높아서 나타난 결과로 사료된다. 조단백질은 대조군과 토마토 분말 $4 \%$ 및 $8 \%$ 첨가

Table 2. Proximate analysis of glutinous rice flour, tomato powder, and 'Hwajeon' made with different amounts of tomato powder

\begin{tabular}{|c|c|c|c|c|}
\hline Sample & Moisture & Crude protein & Crude fat & Ash \\
\hline Glutinous rice flour & $36.83 \pm 0.06^{1 \mathrm{a} 2)}$ & $0.68 \pm 0.01^{\mathrm{b}}$ & $0.67 \pm 0.07^{\mathrm{b}}$ & $0.54 \pm 0.11^{\mathrm{b}}$ \\
\hline Tomato powder & $13.58 \pm 0.25^{\mathrm{b}}$ & $1.65 \pm 0.07^{\mathrm{a}}$ & $2.77 \pm 0.01^{\mathrm{a}}$ & $6.98 \pm 0.00^{\mathrm{a}}$ \\
\hline \multicolumn{5}{|l|}{ Hwajeon } \\
\hline Tomato powder $0 \%$ & $46.59 \pm 0.22^{\mathrm{a}}$ & $0.59 \pm 0.02^{\mathrm{b}}$ & $0.42 \pm 0.20^{\mathrm{a}}$ & $0.49 \pm 0.04^{\mathrm{d}}$ \\
\hline Tomato powder $4 \%$ & $45.42 \pm 0.56^{\mathrm{b}}$ & $0.61 \pm 0.02^{\mathrm{b}}$ & $0.50 \pm 0.35^{\mathrm{a}}$ & $0.68 \pm 0.01^{\mathrm{c}}$ \\
\hline Tomato powder $8 \%$ & $45.65 \pm 0.07^{\mathrm{b}}$ & $0.63 \pm 0.00^{\mathrm{b}}$ & $0.59 \pm 0.25^{\mathrm{a}}$ & $0.88 \pm 0.05^{\mathrm{b}}$ \\
\hline Tomato powder $12 \%$ & $42.60 \pm 0.06^{\mathrm{c}}$ & $0.68 \pm 0.02^{\mathrm{a}}$ & $0.51 \pm 0.13^{\mathrm{a}}$ & $1.08 \pm 0.02^{\mathrm{a}}$ \\
\hline
\end{tabular}

\footnotetext{
${ }^{1)}$ Data were the mean \pm SD $(n=3)$.

${ }^{2) a-d}$ Means with the different superscripts within the same column are significantly different at $\mathrm{p}<0.05$.
} 
군에서는 통계적으로 유의성 있는 변화는 나타나지 않았으 나, 토마토 분말 함량이 $12 \%$ 로 증가함에 따라 조단백질도 $0.68 \%$ 로 증가하였다. 조지방 함량은 대조군과 토마토 분말 4-12\% 첨가군에서 $0.42-0.59 \%$ 로 통계적으로 유의성 있는 변 화는 없는 것으로 나타났다. 이는 화전을 기름에 지져 익히는 과정 동안 유사한 양의 기름이 대조군과 실험군에 흡수되는 데 기인하는 것으로 사료된다.

\section{당도 및 $\mathrm{pH}$}

토마토 분말의 첨가량을 달리하여 제조한 화전의 당도와 $\mathrm{pH}$ 를 측정한 결과는 Table 3 과 같다. 토마토 분말을 첨가하 지 않은 대조군의 당도가 $2.8^{\circ} \mathrm{Brix}$ 로 가장 낮았고, 토마토 분말 첨가량이 4-12\%로 증가함에 따라 당도는 3.7-5.2 ${ }^{\circ} \mathrm{Brix}$ 로 높아지는 경향을 보였다. 토마토에는 glucose, fructose와 소량의 sucrose가 함유되어 있으며(Baldwin 등, 1998; Tadesse 등, 2012), 이들 당 성분에 의해 토마토 분말 첨가량에 비례 하여 화전의 당도가 증가한 것으로 사료된다.

화전의 $\mathrm{pH}$ 를 측정한 결과, 토마토 분말을 첨가하지 않고 제조한 대조군의 $\mathrm{pH}$ 는 5.90 으로 가장 높았고, 토마토 분말 첨가량이 4-12\%까지 증가함에 따라 $\mathrm{pH}$ 는 5.13-4.65로 감소 하는 경향을 보였다. 토마토에는 특유의 신맛에 기여하는 citric acid, malic acid 등이 함유되어 있으며(Agius 등, 2018), 이들 유기산에 의해 대조군에 비해 토마토 분말을 첨가한 화 전의 $\mathrm{pH}$ 가 낮아진 것으로 사료된다. 토마토 분말을 첨가하 여 제조한 죽(Choi와 Kim, 2015), 국수(Kim 등, 2015) 및 베
이글(Kim 등, 2016a)의 선행연구에서도 토마토 분말 첨가량 에 비례하여 $\mathrm{pH}$ 가 낮게 나타나 본 연구와 유사한 결과를 나 타냈다.

\section{경도}

토마토 분말을 첨가하여 제조한 반죽과 화전의 경도 (hardness)를 측정한 결과는 Table 4 와 같다. 화전 반죽의 경 도는 토마토 분말을 첨가하지 않은 대조군에서 가장 낮았고, 토마토 분말 첨가량이 증가함에 따라 다소 높아지는 경향을 보였다. 화전의 경도는 대조군과 토마토 분말을 $4-8 \%$ 첨가한 실험군 간의 통계적으로 유의성 있는 차이는 없는 것으로 나 타났다. 강황 가루 첨가 화전(Han과 Surh, 2017)에서는 강황 가루 첨가량에 따라 반죽의 경도는 유의적 차이가 없고, 화전 의 경도는 증가하는 경향을 보여 본 연구와 다른 결과를 나타 냈다. 일반적으로 화전의 경도는 부재료에 포함된 전분의 종 류, 부재료의 물 결합력, 조리 중 나타나는 탈수, 열전달 매체 인 기름으로 용출되는 지용성 성분들이 기름의 물리적 특성에 영향을 끼쳐 조직감을 변화시킬 수 있다(Han과 Surh, 2017; Lee와 Im, 2013; Surh와 Koh, 2014).

\section{색도}

토마토 분말을 첨가하여 만든 찹쌀 반죽과 완성된 화전의 색도는 Table 5 와 같다. 반죽과 화전 모두에서 토마토 분말을 첨가하지 않고 제조한 대조군에서 밝기를 나타내는 명도 $\left(\mathrm{L}^{*}\right)$ 가 가장 높게 나타났고, 토마토 분말 함량이 증가함에 따라

Table 3. Sugar contents and pH of 'Hwajeon' made with different amount of tomato powder

\begin{tabular}{ccccc}
\hline & \multicolumn{3}{c}{ Tomato powder (\%) } \\
\cline { 2 - 5 } Measurement & 0 & 4 & 8 & 12 \\
\hline Sugar contents ( ${ }^{\circ}$ Brix) & $2.8 \pm 0.00^{1) \mathrm{d} 2)}$ & $3.7 \pm 0.00^{\mathrm{c}}$ & $4.6 \pm 0.00^{\mathrm{b}}$ & $5.2 \pm 0.00^{\mathrm{a}}$ \\
$\mathrm{pH}$ & $5.90 \pm 0.02^{\mathrm{a}}$ & $5.13 \pm 0.01^{\mathrm{b}}$ & $4.82 \pm 0.01^{\mathrm{c}}$ & $4.65 \pm 0.01^{\mathrm{d}}$ \\
\hline
\end{tabular}

${ }^{1)}$ Data were the mean \pm SD $(n=3)$.

${ }^{2) a-d}$ Means with the different superscripts within the same row are significantly different at $\mathrm{p}<0.05$.

Table 4. Hardness of dough and 'Hwajeon' made with different amount of tomato powder

\begin{tabular}{ccccc}
\hline & \multicolumn{4}{c}{ Tomato powder (\%) } \\
\cline { 2 - 5 } Measurement & 0 & 4 & 8 & 12 \\
\hline Dough & $11,599 \pm 2.83^{1) \mathrm{b} 2)}$ & $11,751 \pm 74.95^{\mathrm{ab}}$ & $11,880 \pm 147.08^{\mathrm{a}}$ & $11,976 \pm 25.46^{\mathrm{a}}$ \\
Hwajeon & $11,410 \pm 205.06^{\mathrm{a}}$ & $11,548 \pm 226.98^{\mathrm{a}}$ & $11,830 \pm 54.45^{\mathrm{a}}$ & $11,399 \pm 301.93^{\mathrm{a}}$ \\
\hline
\end{tabular}

${ }^{1)}$ Data were the mean \pm SD $(n=3)$

2)a,b Means with the different superscripts within the same row are significantly different at $\mathrm{p}<0.05$. 
Table 5. Changes in Hunter's color values of 'Hwajeon' made with different amounts of tomato powder

\begin{tabular}{|c|c|c|c|c|c|}
\hline \multirow{2}{*}{\multicolumn{2}{|c|}{ Measurement }} & \multicolumn{4}{|c|}{ Tomato powder $(\%)$} \\
\hline & & 0 & 4 & 8 & 12 \\
\hline \multirow{3}{*}{ Dough } & $\mathrm{L}$ & $77.15 \pm 0.50^{1) \mathrm{a} 2)}$ & $72.93 \pm 0.69^{\mathrm{a}}$ & $70.59 \pm 0.14^{b}$ & $65.88 \pm 0.60^{\mathrm{c}}$ \\
\hline & $\mathrm{a}$ & $-0.30 \pm 0.01^{\mathrm{d}}$ & $1.67 \pm 0.03^{\mathrm{c}}$ & $2.94 \pm 0.06^{\mathrm{b}}$ & $4.23 \pm 0.08^{\mathrm{a}}$ \\
\hline & $\mathrm{b}$ & $4.76 \pm 0.04^{\mathrm{c}}$ & $13.87 \pm 0.15^{\mathrm{b}}$ & $19.38 \pm 0.44^{\mathrm{a}}$ & $18.97 \pm 0.42^{\mathrm{a}}$ \\
\hline \multirow{3}{*}{ Hwajeon } & $\mathrm{L}$ & $55.04 \pm 0.27^{\mathrm{a}}$ & $44.37 \pm 0.22^{b}$ & $44.37 \pm 0.57^{\mathrm{c}}$ & $39.55 \pm 0.27^{\mathrm{d}}$ \\
\hline & $\mathrm{a}$ & $-0.62 \pm 0.06^{\mathrm{c}}$ & $2.75 \pm 0.12^{\mathrm{b}}$ & $2.75 \pm 0.12^{\mathrm{b}}$ & $3.44 \pm 0.26^{\mathrm{a}}$ \\
\hline & $\mathrm{b}$ & $5.34 \pm 0.34^{\mathrm{d}}$ & $9.42 \pm 0.27^{\mathrm{a}}$ & $9.42 \pm 0.38^{\mathrm{b}}$ & $7.22 \pm 0.28^{\mathrm{c}}$ \\
\hline
\end{tabular}

${ }^{1)}$ Data were the mean \pm SD $(n=3)$.

${ }^{2) a-d}$ Means with the different superscripts within the same row are significantly different at $\mathrm{p}<0.05$.

명도가 감소하였다. 적색도를 나타내는 $\mathrm{a}$ *값은 토마토 분말 을 첨가하지 않고 제조한 반죽과 화전이 대조군에 비해 높게 나타났고, 토마토 분말 함량에 비례하여 a*값이 증가함을 확 인하였다. 반죽의 경우, 대조군의 적색도는 -0.30 이었고, 토 마토 분말 함량이 4-12\%까지 증가함에 따라 적색도도 1.674.23까지 높아졌다. 완성된 화전에서도 토마토 분말을 포함 하지 않은 대조군의 적색도는 -0.62였고, 토마토 분말을 4- $12 \%$ 까지 첨가하여 제조한 화전에서는 2.75-3.44까지 적색 도가 증가하였다. 황색도를 나타내는 $\mathrm{b}$ *값은 토마토 분말을 첨가하지 않고 제조한 반죽에서는 4.76이었고, 토마토 분말 을 4\% 및 $8 \%$ 첨가한 반죽에서는 13.87 및 19.38로 증가하였 다. 다만, 토마토 분말을 $12 \%$ 첨가한 반죽의 황색도는 18.97 로 $8 \%$ 첨가군과 비교할 때, 통계적으로 유의성 있는 차이는 나타나지 않았다. 완성된 화전에서도 토마토 분말을 첨가하 지 않은 대조군의 황색도가 5.34로 가장 낮았고, 토마토 분말 을 $4 \%$ 첨가하여 제조한 화전에서는 9.42 로 대조군에 비해 황 색도가 증가하였으나, $8 \%$ 첨가군과는 유의성 있는 차이가 관찰되지 않았고, 토마토 분말을 $12 \%$ 첨가하여 제조한 화전 의 황색도는 7.22 로 토마토 분말 $4 \%$ 및 $8 \%$ 첨가군에 비해 감소하였다.

토마토 분말에는 붉은색을 나타내는 라이코펜과 주황색을 나타내는 카로티노이드계의 색소물질을 함유하고 있어 반죽 과 화전의 적색에 기여한 것으로 사료된다. 토마토 분말을 첨 가하여 제조한 설기떡(Lee와 Chun, 2008), 국수(Kim 등, 2015), 베이글(Kim 등, 2016a) 등의 선행연구에서도 토마토 분말의 첨가량이 증가함에 따라 적색도가 높아져, 본 연구와 유사한 경향을 보였다. 익히지 않은 반죽에 비해 기름에 익힌 화전에서 황색도의 변화가 일정하지 않은 것으로 나타났는 데, 이는 화전을 익히는 과정에서 열의 세기, 기름의 양, 가열 시간 등의 외부 환경적인 영향을 받기 때문으로 사료된다. 화
전 반죽을 기름으로 지지는 동안 토마토에 함유된 색소 성분 과 당, 아미노산 등이 반응하여 비효소적 갈변반응을 일으키 고, 기름에 지지는 조리과정 중에도 화전 표면에서 색 변화가 일어나 화전의 최종 색도에 영향을 미치는 발생한 결과로 보 고하고 있다(Han과 Surh, 2017; Jang과 Park, 2003; Lee 등, 2003).

\section{총폴리페놀 및 총플라보노이드 함량}

토마토 분말 첨가 화전의 총폴리페놀 및 총플라보노이드 함량 분석결과는 Table 6과 같다. 토마토 분말을 첨가하지 않 은 화전의 총폴리페놀 함량은 $1 \mathrm{~g}$ 당 gallic acid를 기준으로 $16.94 \mu \mathrm{g}$ 으로 가장 낮았고, 토마토 분말 첨가량에 비례해 총 폴리페놀 함량도 증가하였다. 즉, 토마토 분말을 4,8 및 $12 \%$ 첨가한 화전에서 총폴리페놀 함량은 $61.51 \mu \mathrm{g}, 120.44 \mu \mathrm{g}$, $158.94 \mu \mathrm{g}$ 으로 대조구에 비해 각각 3.6배, 7.1배 및 9.3배 증 가하였다.

토마토 분말을 첨가하지 않고 제조한 화전의 총플라보노 이드 함량은 $1 \mathrm{~g}$ 당 quercetin을 기준으로 $11.96 \mu \mathrm{g}$ 이었고, 토마토 분말 첨가량이 증가할수록 화전에 포함된 총플라보노 이드 함량도 증가하였다. 즉, 토마토 분말을 4,8 및 $12 \%$ 첨 가함에 따라 총플라보노이드 함량은 $14.09 \mu \mathrm{g}, 18.95 \mu \mathrm{g}$, $22.57 \mu \mathrm{g}$ 으로 증가하는 것으로 나타났다.

토마토에는 hydroxycinnamic acids, flavanones, flavonols, rutin, kaempferol-3-rutinoside, querciein-3-rutinnoside, 5caffeoylquinic acid querciein-3-rutinnoside, 5-caffeoylquinic acid 등의 폴리페놀 성분들을 포함하고 있고, 이들은 강력한 항산화제로 작용한다(Marti 등, 2016; Minoggio 등, 2003). 토마토 분말 첨가량이 증가할수록 화전의 총폴리페놀 함량도 증가한 것으로 사료된다. 토마토 분말을 첨가하여 제조한 소 시지(Na와 Joo, 2012), 머랭쿠키(Kim 등, 2016b) 및 국수 
Table 6. Total polyphenol and total flavonoid contents of 'Hwajeon' made with different amounts of tomato powder

\begin{tabular}{|c|c|c|c|c|}
\hline \multirow{2}{*}{ Contents } & \multicolumn{4}{|c|}{ Tomato powder $(\%)$} \\
\hline & 0 & 4 & 8 & 12 \\
\hline Total polyphenol $\left(\mu \mathrm{g} \mathrm{GAE}^{1)} / \mathrm{g}\right)$ & $16.94 \pm 0.27^{3) \mathrm{d} 4} 4$ & $61.51 \pm 0.78^{\mathrm{c}}$ & $120.44 \pm 1.77^{\mathrm{b}}$ & $158.94 \pm 1.52^{\mathrm{a}}$ \\
\hline Total flavonoid $\left(\mu \mathrm{g} \mathrm{QE}^{2} / \mathrm{g}\right)$ & $11.96 \pm 0.45^{\mathrm{d}}$ & $14.09 \pm 0.33^{\mathrm{c}}$ & $18.95 \pm 0.63^{\mathrm{b}}$ & $22.57 \pm 0.37^{\mathrm{a}}$ \\
\hline
\end{tabular}

(Kim 등, 2015)에서도 총폴리페놀 함량은 토마토 분말 첨가 구가 무첨가구보다 유의적으로 높게 측정되었고, 토마토 분 말의 첨가 비율이 증가함에 따라 함량이 높아지는 것으로 보 고하고 있어 본 연구와 유사한 경향이었으나, 같은 연구에서 플라보노이드 함량의 경우, 토마토 분말 첨가 유무 및 첨가 비율에 관계없이 유의적 차이를 보이지 않은 것으로 보고하 고 있다.

\section{항산화 활성}

토마토 분말을 첨가하여 제조한 화전의 항산화 활성을 알 아보기 위해 DPPH 및 $\mathrm{ABTS}$ 라디칼 소거능을 측정한 결과 는 Table 7과 같다. DPPH 라디칼 소거 활성은 토마토 분말 을 첨가하지 않은 대조군에서 $30.17 \%$ 로 나타났고, 토마토 분 말을 4,8 및 $12 \%$ 첨가한 화전에서 각각 $68.01 \%, 78.01 \%$, $78.23 \%$ 로 증가했다. ABTS 라디칼 소거 활성의 경우, 대조군 은 $20.70 \%$ 로 가장 낮았고, 토마토 분말 첨가량 비율에 따라 각각 $54.32 \%, 73.22 \%, 79.20 \%$ 로 토마토 분말 첨가량이 증가 할수록 높게 나타났다. 환원력은 DPPH 및 ABTS 라디칼 소 거 활성과 유사한 경향을 보였다. 토마토 분말을 첨가하지 않 은 대조군의 환원력은 0.14 로 가장 낮았고, 토마토 분말 첨가 량이 4-12\%로 증가함에 따라 환원력은 0.96-1.06으로 높아 졌다.

폴리페놀 물질의 함량이 높을수록 DPPH와 ABTS 라디칼 소거활성이 증가하는 것으로 알려져 있다(Rohman 등, 2010;
Tsao, 2010). 화전에 첨가한 토마토 분말에 함유된 페놀화합 물과 라이코펜을 포함한 카로티노이드계의 항산화 성분들이 유리 라디칼을 환원시켜 항산화 활성을 높인 것으로 사료된 다. 토마토 분말 첨가 시폰케이크(Paik 등, 2013), 강황 분말 첨가 화전(Han과 Surh, 2017), 아로니아 분말 첨가 설기떡 (Hwang과 Hwang, 2015) 등의 연구에서도 항산화 활성이 우 수한 분말 재료의 첨가량이 증가함에 따라 라디칼 소거 활성 이 높아지는 것으로 보고하고 있다. 이상의 결과를 통해 화전 제조 시, 토마토 분말을 첨가하면 항산화 활성이 높은 폴리페 놀 및 플라보노이드 함량이 증가하고, 이에 따라 항산화 활성 도 증가하는 긍정적인 효과를 나타냄을 확인할 수 있었다.

\section{요 약}

본 연구에서는 찹쌀가루 중량 대비 토마토 분말 함량을 $4-12 \%$ 까지 달리하여 화전을 제조하고, 화전의 이화학적 품 질특성, 기능성 성분의 함량 및 항산화 활성을 측정하여 토마 토 분말 첨가 화전의 최적 배합비를 선정하고자 하였다. 화전 의 수분함량은 42.60-46.59\%로 토마토 분말을 첨가하지 않 은 화전에서 가장 높았고, 토마토 분말을 첨가한 경우엔 대조 군에 비해 수분함량이 감소하는 경향을 보였다. 화전의 조단 백질 함량은 대조군과 토마토 분말 4-8\% 첨가군에서는 통계 적으로 유의적인 차이를 보이지 않다가, 토마토 분말 $12 \%$ 첨 가군에서는 증가하였다. 토마토 분말의 첨가량이 증가함에

Table 7. Antioxidant activities of 'Hwajeon' made with different amounts of tomato powder

\begin{tabular}{ccccc}
\hline & \multicolumn{4}{c}{ Tomato powder (\%) } \\
\cline { 2 - 5 } Measurement & 0 & 4 & 8 & 12 \\
\hline DPPH radical scavenging activity (\%) & $\left.30.17 \pm 0.93^{1) \mathrm{c} 2}\right)$ & $68.01 \pm 1.57^{\mathrm{b}}$ & $78.01 \pm 0.40^{\mathrm{a}}$ & $78.23 \pm 0.35^{\mathrm{a}}$ \\
ABTS radical scavenging activity (\%) & $20.70 \pm 0.84^{\mathrm{c}}$ & $54.32 \pm 1.03^{\mathrm{b}}$ & $73.22 \pm 1.93^{\mathrm{a}}$ & $79.20 \pm 1.12^{\mathrm{a}}$ \\
Reducing power (absorbance at $720 \mathrm{~nm})$ & $0.14 \pm 0.00^{\mathrm{d}}$ & $0.96 \pm 0.01^{\mathrm{c}}$ & $1.04 \pm 0.02^{\mathrm{b}}$ & $1.06 \pm 0.00^{\mathrm{a}}$ \\
\hline
\end{tabular}

${ }^{1)}$ Data were the mean $\pm \mathrm{SD}$ of triplicate experiment.

${ }^{2) a-d}$ Values with the different superscript within the same row are significantly different at $\mathrm{p}<0.05$. 
따라 회분의 함량은 증가하였고, 조지방은 수치적으로는 증 가하다가 감소하는 경향을 보였으나, 통계적인 유의성은 없 는 것으로 나타났다. 화전에 첨가한 토마토 분말 함량에 비례 하여 당도는 증가하였고 $\mathrm{pH}$ 는 감소하는 경향을 보였다. 화전 의 경도는 대조군과 토마토 분말 첨가군 간의 유의적 차이는 나타나지 않았다. 토마토 분말 첨가량에 비례하여 화전 반죽 과 완성된 화전의 $\mathrm{L}^{*}$ 값은 감소하고 $\mathrm{a}$ *값은 증가하였다. 화전 에 함유된 총폴리페놀 및 총플라보노이드는 대조군에 비해 토마토 분말 첨가량이 증가함에 따라 높게 나타났다. 또한 $\mathrm{DPPH}$ 및 $\mathrm{ABTS}$ 라디칼 소거활성과 환원력으로 측정한 항산 화 활성도 토마토 분말 첨가량이 증가할수록 높은 값을 보였 다. 이상의 결과로 볼 때, 토마토 분말을 첨가한 화전의 제품 화 가능성은 긍정적으로 사료된다. 총폴리페놀과 총플라보노 이드 함량은 토마토 분말 첨가 비율이 증가할수록 높아지는 것으로 나타났는데, 총플라보노이드 함량에 비해 총폴리페놀 함량의 변화가 두드러지게 나타났다. DPPH 및 ABTS 라디 컬 소거능은 토마토 분말 첨가 비율이 증가함에 따라 높아지 는 경향을 보였고, $8 \%$ 첨가군과 $12 \%$ 첨가군에서 유의적 차 이를 보이지 않았다. 환원력 또한 토마토 분말 첨가비율 증가 에 따라 높아지는 것으로 나타났다. 이상의 결과들로 볼 때 토마토가 지닌 항산화 활성이 기름에 지져 익혀내는 화전에 서 증가함이 확인된 바, 화전에 토마토 분말을 첨가하여 기능 성을 더한 식품으로 개발할 가치가 있는 것으로 사료된다.

\section{감사의 글}

본 연구는 한국연구재단 기본연구지원사업(과제번호 2019 $\mathrm{R} 1 \mathrm{~F} 1 \mathrm{~A} 1058764)$ 의 지원에 의해 이루어진 것이며, 그 지원에 감사드립니다.

\section{Conflict of interests}

The authors declare no potential conflict of interest.

\section{ORCID}

Yoon-Jung Jung https://orcid.org/0000-0002-8012-004X

Eun-Sun Hwang https://orcid.org/0000-0001-6920-3330

\section{References}

Agius C, von Tucher S, Poppenberger B, Rozhon W. Quantification of sugars and organic acid in tomato fruits. MethodsX, 5, 537-550 (2018)
AOAC. Official Methods of Analysis of AOAC International. 16th ed, Association of Official Analytical Chemists. Washington DC, USA, p 1-26 (1995)

Baldwin EA, Scott JW, Einstein MA, Malundo TMM, Carr BT, Shewfelt RL, Tandon KS. Relationship between sensory and instrumental analysis for tomato flavor. J Amer Soc Hort Sci, 123, 906-915 (1998)

Chandra HM, Shanmugaraj BM, Srinivasan B, Ramalingam S. Influence of genotypic variations on antioxidant properties in different fractions of tomato. J Food Sci, 77, C1174-C1178 (2012)

Chaudhary P, Sharma A, Singh B, Nagpal AK. Bioactivities of phytochemicals present in tomato. J Food Sci Technol, 55, 2833-2849 (2018)

Cheng HM, Koutsidis G, Lodge JK, Ashor AW, Siervo M, Lara J. Lycopene and tomato and risk of cardiovascular diseases: A systematic review and meta-analysis of epidemiological evidence. Crit Rev Food Sci Nutr, 59, 141-158 (2019)

Cheung LM, Cheung PCK, Ooi VEC. Antioxidant activity and total phenolics of edible mushroom extracts. Food Chem, 81, 249-255 (2003)

Choi EJ, Kim MH. The health benefits of porridge with tomato powder. Korean J Food Cook Sci, 31, 233-240 (2015)

Giovannucci E, Ascherio A, Rimm EB, Stampfer MJ, Colditz GA, Willett WC. Intake of carotenoids and retinol in relation to risk of prostate cancer. J Natl Cancer Inst, 87, 1767-1776 (1995)

Han A, Surh J. Quality characteristics and antioxidant activities of pan-fried Hwajeon added with curcuma as a functional ingredient. Korean J Food Sci Technol, 49, 296-303 (2017)

Hwang YR, Hwang ES. Quality characteristics and antioxidant activity of Sulgidduk prepared by addition of aronia powder (Aronia melanocarpa). Korean J Food Sci Technol, 47, 452-459 (2015)

Jang MS, Park JE. Sensory and physical characteristics of Hwajeun prepared with various kinds of dipping syrups. Korean J Soc Food Cookery Sci, 19, 659-666 (2003)

Kim DS, Ahn JB, Choi WK, Han GP, Park ML, Kang BN, Kim DH, Choi SH. Quality characteristics of noodles added with tomato powder. Korean J Culi Res, 21, 129-142 (2015) 
Kim KH, Kim YS, Hong MS, Yook HS. Quality characteristics of bagel added with tomato powder. J Korean Soc Food Sci Nutr, 45, 360-365 (2016a)

Kim KH, Kim YS, Hong MS, Yook HS. Quality characteristics of meringue cookies added with tomato powder. J Korean Soc Food Sci Nutr, 45, 366-371 (2016b)

Kim KP, Kim KH, Kim YS, Yook HS. Quality characteristics of crackers with tomato concentrate. J Korean Soc Food Sci Nutr, 46, 77-82 (2017)

Kim MY, Chun SS. Quality characteristics of Sulgidduk with tomato powder. Korean J Food Cookery Sci, 24, 412-418 (2008)

Lee BY, Kim NH, Kim SI, Kim SG, Kim JS, Surh J. Preparation and characterization of physicochemical and sensory properties of Hwajeon added with wild grape extract. Korean J Food Sci Technol, 43, 588-596 (2001)

Lee JG, Im MH. Effect of processing treatment on physicochemical characteristics of brown rice varieties with different amylose content. Korean J Soc Food Sci Technol, 45, 613-618 (2013)

Lee SH, Park JE, Jang MS. Sensory and physical characteristics of Hwajeun depended on the various levels of oil amounts and frying time. Korean J Soc Food Cook Sci, 19, 765-771 (2003)

Marti R, Rosello S, Cebolla-Cornejo J. Tomato as a source of carotenoids and polyphenols targeted to cancer prevention. Cancers, 8, 58 (2016)

Martinez-Huelamo M, Vallverdu-Queralt A, Di Lecce G, Valderas-Martinez P, Tulipani S, Jauregui O, EscribanoFerrer E, Estruch R, Illan M, Lamuela-Raventos RM. Bioavailability of tomato polyphenols is enhanced by processing and fat addition: Evidence from a randomized feeding trial. Mol Nutr Food Res, 60, 1578-1589 (2016)

Minoggio M, Bramati L, Simonetti P, Gardana C, Lemoli L, Santangelo E, Mauri PL, Spigno P, Soressi GP, Pietta PG. Polyphenol pattern and antioxidant activity of different tomato lines and cultivars. Ann Nutr Metab, 47, 64-69 (2003)

$\mathrm{Na}$ Y, Joo N. Processing optimization and antioxidant activity of sausage prepared with tomato powder. Korean J Food Cookery Sci, 28, 195-206 (2012)

Oyaizu M. Studies on product of browning reaction: Antioxidative activities of products of browning reaction prepared from glucoseamine. Jap J Nutr Diet, 44, 307-315 (1986)

Paik J, Kim S, An H, Joo N. Processing optimization and antioxidant activity of chiffon cake prepared with tomato powder. J Korean Diet Assoc, 19, 1-13 (2013)

Palozza P, Simone RE, Catalano A, Mele MC. Tomato lycopene and lung cancer prevention: From experimental to human studies. Cancers, 3, 2333-2357 (2011)

Re R, Pellegrini N, Proteggente A, Pannala A, Yang M, Rice-Evans C. Antioxidant activity applying an improved ABTS radical cation decolorization assay. Free Radic Biol Med, 26, 1231-1237 (1999)

Rohman A, Riyanto S, Yuniarti N, Saputra WR, Utami R, Mulatsih W. Antioxidant activity, total phenolic, and total flavaonoid of extracts and fractions of red fruit (Pandanus conoideus Lam). Int Food Res J, 17, 97-106 (2010)

Rowles JL 3rd, Ranard KM, Applegate CC, Jeon S, An R, Erdman JW Jr. Processed and raw tomato consumption and risk of prostate cancer: A systematic review and dose-response meta-analysis. Prostate Cancer Prostatic Dis, 21, 319-336 (2018)

Sahin K, Orhan C, Tuzcu M, Tastan H, Bilir B, Sahin N, Oner DA, Kucuk O. Tomato powder modulates NF- $\kappa \mathrm{B}$, mTOR, and Nrf2 pathways during aging in healthy rats. J Aging Res, 2019, 1643243 (2019)

Surh J, Koh E. Effect of pan-frying on anthocyanin content in Hwajeon with varying proportion of glutinous black rice flour. Korean J Food Cook Sci, 30, 378-384 (2014)

Tadesse T, Workneh TS, Woldetsadik K. Effect of varieties on changes in sugar content and marketability of tomato stored under ambient conditions. Afri J Agric Res Soc, 7, 2124-2130 (2012)

Tsao R. Chemistry and biochemistry of dietary polyphenols. Nutrients, 2, 1231-1246 (2010) 